\title{
A REACTION OF 4,5-DIPHENYLIMIDAZOLE NITRATION IN THE PRESENCE OF SOME 3D-METALS NITRATES
}

\author{
Irina Voda ${ }^{\mathrm{a}^{*}}$, Vadim Druta ${ }^{\mathrm{a}}$, Constantin Indricean ${ }^{\mathrm{a}}$, Iurie Ciumacov ${ }^{\mathrm{b}}$, Constantin Turta $^{\mathrm{a}^{*}}$ \\ ${ }^{a}$ Institute of Chemistry, Academy of Sciences of Moldova, 3, Academiei str., MD-2028, Chisinau, Moldova \\ ${ }^{b}$ Institute of Applied Physics, Academy of Sciences of Moldova, 5, Academiei str., MD-2028,Chisinau, Moldova \\ E-mail : iravoda@gmail.com, Phone :+(373 22) 739722 \\ E-mail :turtac@yahoo.com, Phone :+(373 22) 739755
}

\begin{abstract}
Three new coordination compounds of Cobalt(II), Nickel(II) and Zinc(II) with 4,5-diphenyl-2nitroimidazole ligand of general formulae $\left[\mathrm{M}\left(\mathrm{C}_{3} \mathrm{~N}_{2}\left(\mathrm{C}_{6} \mathrm{H}_{5}\right)_{2} \mathrm{NO}_{2}\right)_{2}\left(\mathrm{CH}_{3} \mathrm{OH}\right)_{2}\right]$ have been synthesized and characterised by elemental, thermogravimetric, X-ray diffraction analysis, IR, UV-Vis and NMR spectroscopies.
\end{abstract}

Keywords: solvothermal synthesis; Cobalt(II), Nickel(II), Zinc(II) complexes; 4,5-diphenyl-2-nitroimidazole, physicochemical properties.

\section{Introduction}

Imidazole's fragment is a part of histidine molecule, which is an important component of many proteins. It plays an important role in enzymes activity [1-4], and can also form various supramolecular structures with metal ions [5-6]. From this point of view coordination compounds of imidazole are of particular interest to be investigated. Of interest are compounds of 4,5-diphenylimidazole which have specific steric regulations and electronic structure.

It is known that nitro-imidazole compounds have a high microbial activity and are widely used in medicine [1]. Direct nitration reaction of imidazole and its derivatives at $\mathrm{C} 2$ position is difficult to realise - it can be done in several stages. On the other hand there is known the natural compound azomicin which contain nitro-group in position $\mathrm{C} 2$ of imidazole and has strong antibiotic properties [2].

In this paper the synthesis and physico-chemical properties of 4,5-diphenyl-2-nitroimidazole and three new coordination compounds of $\left[\mathrm{M}\left(\mathrm{C}_{3} \mathrm{~N}_{2}\left(\mathrm{C}_{6} \mathrm{H}_{5}\right)_{2} \mathrm{NO}_{2}\right)_{2}\left(\mathrm{CH}_{3} \mathrm{OH}\right)_{2}\right]$ composition are presented.

\section{Results and discussion}

During solvothermal synthesis an unexpected reaction of 4,5-diphenylimidazole nitration in the presence of some $3 \mathrm{~d}$ metals nitrates takes place. Thus, under solvothermal conditions $\left(170^{\circ} \mathrm{C}, 3 \mathrm{~h}\right)$ in methanol the cobalt, nickel or zinc nitrate react with 4,5-diphenyilimidazole and the 4,5-diphenyl-2-nitroimidazole and its complexes of $\left[\mathrm{M}\left(\mathrm{C}_{3} \mathrm{~N}_{2}\left(\mathrm{C}_{6} \mathrm{H}_{5}\right)_{2} \mathrm{NO}_{2}\right)_{2}\left(\mathrm{CH}_{3} \mathrm{OH}\right)_{2}\right]$ composition, where $\mathrm{M}=\mathrm{Co}$ (II) (I), Ni(II) (II) and $\mathrm{Zn}(\mathrm{II})$ (III), have been obtained (Scheme 1).

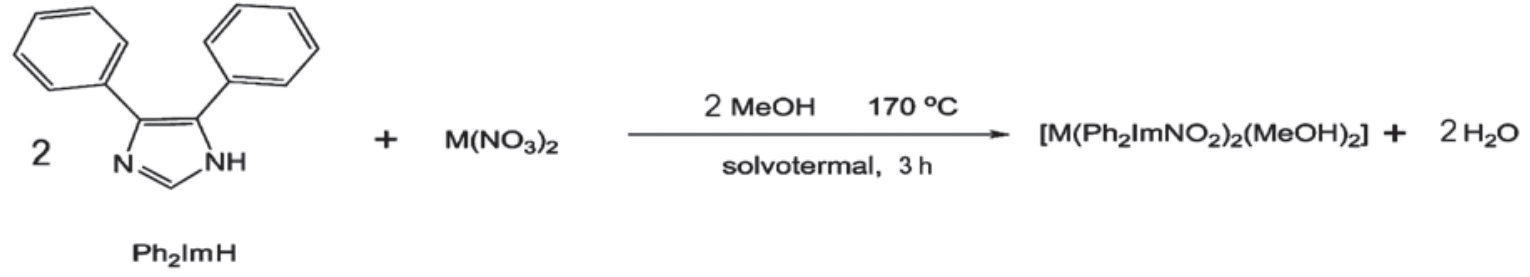

Scheme 1. The synthesis of complexes I-III

The analytical data analysis is in good agreement with the presented compositions.

\section{Infrared spectra}

IR spectra of complexes I-III, free ligands 4,5-diphenylimidazole and 4,5-diphenyl-2-nitroimidazole (IV) were studied (experimantal part). Comparing these spectra one can see that complexes contain 4,5-diphenyl-2-nitroimidazole. In addition new bands for coordinated methanol (for $v(\mathrm{OH})-3650-3676 \mathrm{~cm}^{-1}, v_{\text {as, }}(\mathrm{CH})\left(\mathrm{CH}_{3}\right)-2989-2772, \delta\left(\mathrm{CH}_{3}\right)$ $-1437-1438$ and $\left.1386-1400 \mathrm{~cm}^{-1}, v(\mathrm{C}-\mathrm{OH})-1014-1025 \mathrm{~cm}^{-1}\right)$ were observed. They correspond to the valence vibrations of $\mathrm{OH}$ group, stretching and deformation vibrations of $\mathrm{CH}_{3}$ group, and $\mathrm{C}-\mathrm{OH}$ valence vibration, respectively. 
Asymmetric valence vibration of $\mathrm{NO}_{2}$ group is designated by the appearance of strong bands in the spectra of complexes between $1499-1504 \mathrm{~cm}^{-1}$, shifted to the lower energy than the signal of $\mathrm{NO}_{2}$ group in free ligand 4,5-diphenyl2-nitroimidazole $\left(1539 \mathrm{~cm}^{-1}\right)$ indicating its coordination to metal ions. Appearance of absorption bands at $480-540 \mathrm{~cm}^{-1}$ in the spectra of the complexes is due to valence vibrations of the coordination bonds $\mathrm{M}-\mathrm{O}$ and $\mathrm{M}-\mathrm{N}$ [7-8]. In conclusion, IR spectra points in favor of methanol and 4,5-diphenyl-2-nitroimidazole coordination to metal ion.

\section{NMR studies}

${ }^{1} \mathrm{H}$ NMR spectrum of the diamagnetic complex III was analyzed and compared with that of the starting ligand (Figure 1). The spectra allow elucidation of the hyperfine structure. In the ligand's spectrum, the signals in the form of multiplets $\left(\delta=7,30-7,61 \mathrm{ppm}\right.$ (multiplet, $\left.10 \mathrm{H}, \mathrm{CH}_{\mathrm{Ph}}\right)$ ) corresponding to three types of protons of the phenyl ring are well separated, while in complex these bands overlap forming a broadband. This fact may be explained by the presence of the reflection plane, passing through the nitrogen atom of the nitro- group and $\mathrm{C} 2$ carbon atom in the molecule of ligand and the absence of it in the complex molecule. In the first case two phenyl groups of 4,5-diphenylimidazole appear as an entity, but in complex each of 4 phenyl groups appear with their unique spectrum. Quite small differences in chemical displacement values of proton signals lead to an overlap in the spectrum.

In ${ }^{1} \mathrm{H}$ NMR spectrum of complex III signals at 3,85 ppm, corresponding to protons of the $\mathrm{CH}_{3}$ groups of coordinated methanol molecules, were observed. As a result of coordination of methanol molecules to metal ion, there is an additional deshielding of their methyl protons, with shifting of corresponding signals to higher ppm values, than signals known for free methanol (3,31 ppm). May be supposed that the signal of hydroxylic proton of methanol in the spectrum of complex III is partially overlapped by the signals of water protons at $3 \mathrm{ppm}$, which was present in deuterated acetone as impurity.

It should be noted that broadband at $11,67 \mathrm{ppm}$, corresponding to iminic proton of imidazole's ring, disappears in the spectrum of $\mathrm{Zn}(\mathrm{II})$ complex. It shows that by coordination to metal the ligand is deprotonated.
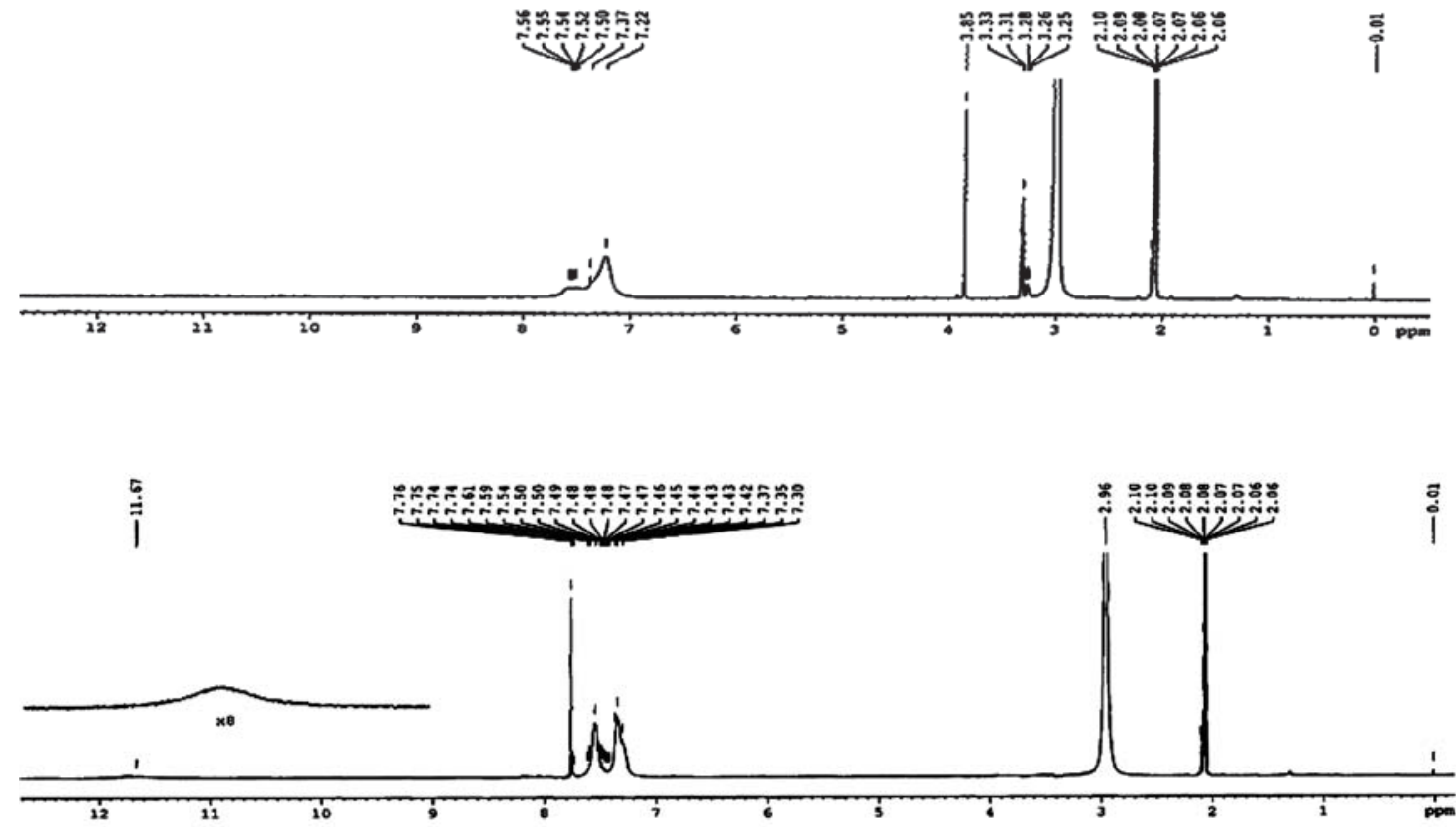

Figure 1. ${ }^{1} \mathrm{HNMR}$ spectra of complex $\left[\mathrm{Zn}\left(4,5-\mathrm{Ph}_{2} \mathrm{ImNO}_{2}\right)_{2}\left(\mathrm{CH}_{3} \mathrm{OH}\right)_{2}\right]$ (up) and 4,5-diphenylimidazole (down)

\section{Magnetic properties}

Magnetic susceptibilities of the samples were determined at room temperature $(287 \mathrm{~K}-283 \mathrm{~K})$ by Gouy method [9]. The following values of the effective molar magnetic moment of complexes I and II were obtained: $\left(\mu_{\mathrm{ef}}\right)_{\mathrm{M}}(\mathbf{I})=$ 5,00 BM; $\left(\mu_{\mathrm{ef}}\right)_{\mathrm{M}}(\mathbf{I I})=3,10 \mathrm{BM}$. These values of magnetic moment are in the early observed limits of this parameter for cobalt(II) and nickel(II) complexes [10]. According to obtained experimental data, it can be argued that the metal ions in complexes are in high spin state and have a distorted octahedral neighborhood, which demonstrates that the ligand field is weak. 


\section{Thermogravimetric analysis}

The results of thermal analysis in air conditions revealed that complexes are stable up to $120-150^{\circ} \mathrm{C}$. At higher temperatures the complexes decompose and there are three steps of decomposition processes. At the first stage (120 $220^{\circ} \mathrm{C}$ ) it was observed a weight loss of $11-12 \%$ which corresponds to elimination of two molecules of coordinated methanol. The second stage $\left(200-300^{\circ} \mathrm{C}\right)$ ends with elimination of $\mathrm{NO}_{2}$-groups, followed by slow decomposition of the residue to form corresponding metal oxides (Scheme 2).

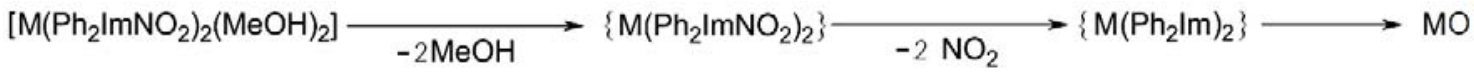

Scheme 2. The scheme of thermal decomposition of I-III compounds

\section{Electronic spectra}

The UV-Vis spectra of complexes I-III and starting ligand 4,5-diphenylimidazole are presented in Figure 2 and values of their parameters - in Table 1 .
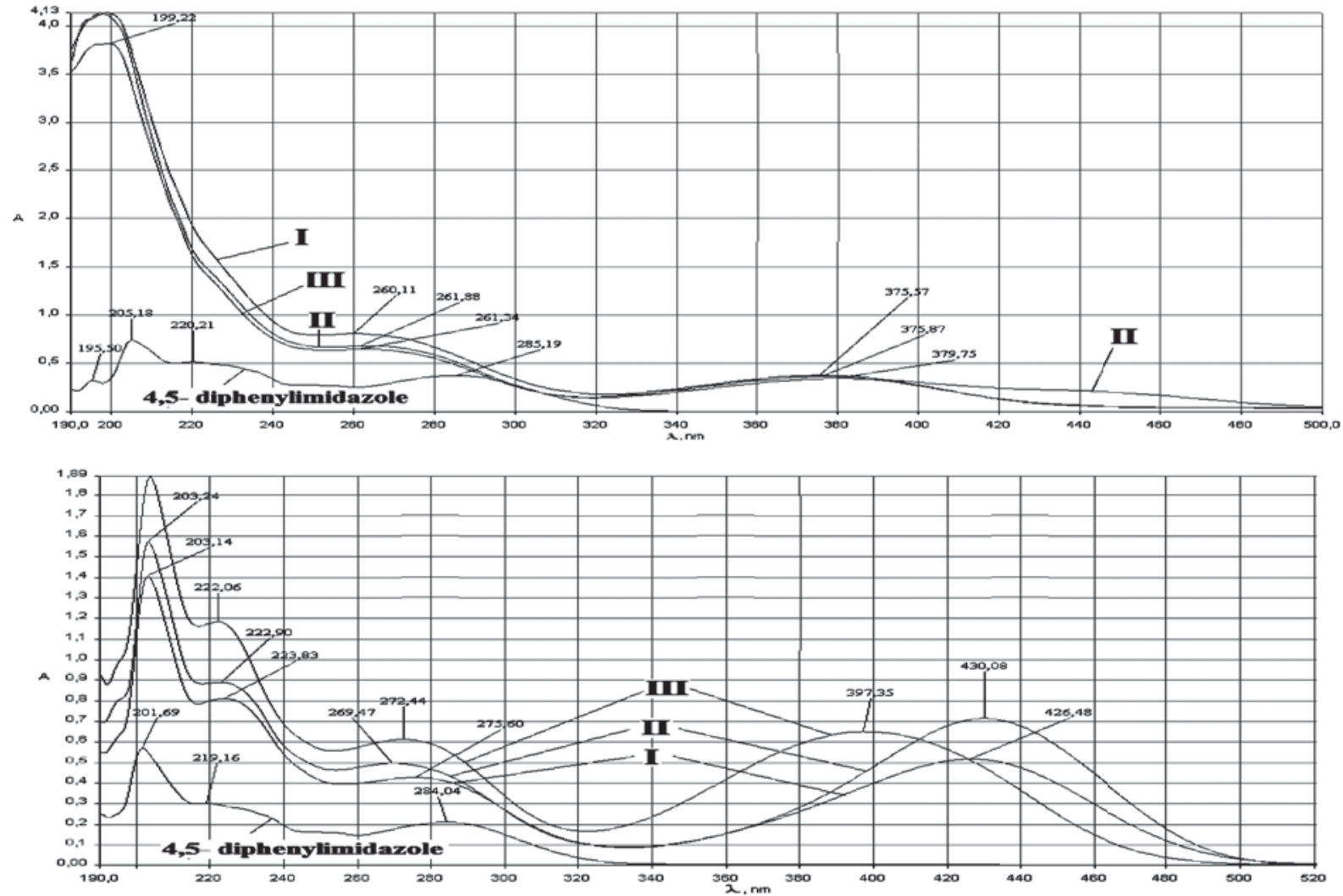

Figure 2. Electronic spectra of complexes I-III and initial ligand 4,5-diphenylimidazole in isopropanol (up) and in ethanol (down)

Table 1

UV-Vis data for investigated substances in different solvents

\begin{tabular}{|c|c|c|c|c|}
\hline \multirow{2}{*}{ Solvent } & \multicolumn{4}{|c|}{$\lambda_{\max }\left(\varepsilon, \times 10^{-3} \mathrm{M}^{-1} \cdot \mathrm{cm}^{-1}\right)$} \\
\cline { 2 - 5 } & $(\mathrm{I})$ & $(\mathrm{II})$ & $(\mathrm{III})$ & 4,5 -diphenylimidazole \\
\hline Isopropanol & $200(276,993)$ & $200(186,288)$ & $199(301,772)$ & $205(17,566)$ \\
\cline { 2 - 5 } & $260(53,401)$ & $262(39,891)$ & $261(51,398)$ & $220(17,370)$ \\
\cline { 2 - 5 } & $376(27,093)$ & $379(20,264)$ & $376(29,501)$ & $285(12,606)$ \\
\hline
\end{tabular}




\begin{tabular}{|c|c|c|c|c|}
\hline \multirow{3}{*}{ Ethanol } & $203(41,630)$ & $203(50,022)$ & $203(52,758)$ & $202(17,635)$ \\
\cline { 2 - 5 } & $224(24,210)$ & $223(28,177)$ & $222(33,218)$ & $219(9,281)$ \\
\cline { 2 - 5 } & $276(12,467)$ & $270(15,424)$ & $273(17,487)$ & $284(6,274)$ \\
\cline { 2 - 5 } & $426(15,106)$ & $430(21,961)$ & $397(18,463)$ & \\
\hline
\end{tabular}

In the starting ligand spectrum there are three absorption bands only in ultraviolet domain (190 - $320 \mathrm{~nm})$, but in the spectra of complexes the absorption bands appear both in the ultraviolet, and in the visible (between 320 and 520 $\mathrm{nm}$ ) domains. Bands in the visible domain are due to metal - ligand charge transfer.

This electron transfer occurs with approximately the same energy in all three studied complexes when isopropanol was used as a solvent - $316-319 \mathrm{~kJ} / \mathrm{mol}$ and showed different values of energy for ethanol: $\mathbf{I}-281 \mathrm{~kJ} / \mathrm{mol}, \mathbf{I I}-279 \mathrm{~kJ} /$ mol, and III - $302 \mathrm{~kJ} / \mathrm{mol}$.

Analyzing electronic spectra of complexes in two solvents with different polarity was observed dipole-dipole interaction of solvent with dissolved molecules. The spectrum of starting ligand shows only a slight shift of the absorption $\Delta \sim 1 \mathrm{~nm}$ ), so the solvent does not influence the nature of the electronic state of the ligand. In the spectra of the complexes appear displacement of the absorption peaks (in ethanol - to higher wavelength values than in the isopropanol) for $\mathbf{I} \Delta=$ $50 \mathrm{~nm}$, for II $\Delta=51 \mathrm{~nm}$, and for III $\Delta=21 \mathrm{~nm}$.

A specific feature of complex II spectra is the appearance of an additional band in the visible domain (450 $\mathrm{nm})$ when using isopropanol. This is probably due to the changes in the symmetry of the complex to a lower one, an effect caused by the nature of the solvent.

When using less polar solvent (isopropanol) the extinction coefficients have two times higher values than for more polar solvent (ethanol), hence for the complexes I and III, the difference being 11987 and $11038 \mathrm{M}^{-1} \cdot \mathrm{cm}^{-1}$ respectively and the complex II the extinction coefficient decreases with $1697 \mathrm{M}^{-1} \cdot \mathrm{cm}^{-1}$.

UV-Vis spectra of the complexes showed high values of extinction coefficients $\left(15106-29501 \mathrm{M}^{-1} \cdot \mathrm{cm}^{-1}\right)$ which potentially allow their use in analytical chemistry.

\section{Structure}

Single crystals of compounds I-III were investigated by X-ray method and their detailed structural study is the subject of separate work [11]. Compounds I-III are isostructural, here is presented only schematic structure of the compounds I-III (Figure 3).

In complexes metal atom coordinates with two deprotonated bidentate ligands $\mathrm{L}_{1}$ (where $\mathrm{L}_{1}=4,5$-diphenyl-2nitroimidazolyl) and two molecules of non-deprotonated $\mathrm{CH}_{3} \mathrm{OH}$. The coordination polyhedron of the metal is a square bi-pyramide $(4+1+1)$, which is determined by oxygen and nitrogen atoms of the deprotonated ligand $\mathrm{L}_{1}$. In all complexes bipyramide's axial positions are occupied by oxygen atoms from nitro-groups of the ligand $\mathrm{L}_{1}$.

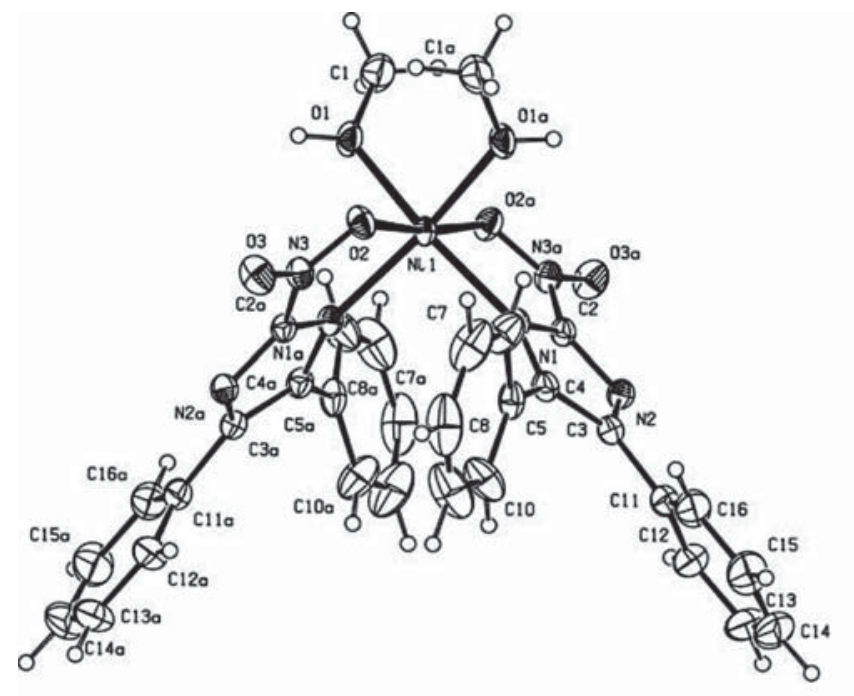

Figure 3. Structure of the complex II

Preliminary research of biological activity performed by colleagues from the Microbiology Institute of ASM showed that adding a solution of Co complex described in this paper in the nutrient composition of Porphyridium cruentum red microalgae increases substantially the content of different useful substances in biomass. 


\section{Conclusions}

By the action of nitrates of $3 \mathrm{~d}$ metals $(\mathrm{Ni}, \mathrm{Zn}, \mathrm{Co})$ under solvothermal conditions was carried out the nitration at the $\mathrm{C} 2$ atom of the imidazole ring of 4,5-diphenylimidazole and nitro-group is involved in complexation of the corresponding metal ions.

The ligand is deprotonated and the nitrogen atom from imidazole ring coordinates the metal. Two molecules of the solvent used in the reaction solvent - methanol - also coordinate the metal through the oxygen atom without deprotonation. Final complexes are neutral, charge compensation of $\mathrm{M}^{2+}$ being performed by ligand deprotonation to form $\mathrm{Ph}_{2} \mathrm{ImNO}_{2}{ }^{-}$. Two residues of $\mathrm{Ph}_{2} \mathrm{ImNO}_{2}^{-}$are bidentatly involved in complex formation. Due to this mode of coordination in the structure there are two metalocycles with five atoms each.

\section{Experimental}

\section{General}

Starting materials $\left(\mathrm{Co}\left(\mathrm{NO}_{3}\right)_{2} \cdot 6 \mathrm{H}_{2} \mathrm{O}, \mathrm{Ni}\left(\mathrm{NO}_{3}\right)_{2} \cdot 6 \mathrm{H}_{2} \mathrm{O}, \mathrm{Zn}\left(\mathrm{NO}_{3}\right)_{2} \cdot 6 \mathrm{H}_{2} \mathrm{O}, 4,5\right.$-diphenylimidazole, $\left.\mathrm{CH}_{3} \mathrm{OH}\right)$ were purchased from commercial sources and used without further purification (reagent grade).

Elemental analysis $(\mathrm{C}, \mathrm{H}, \mathrm{N})$ were carried out by standard methods [12], analysis of metals (Zn, Co, Ni) were done on spectrophotometer AAS-3N (Karl Zeiss Jena) in the Atomic absorption spectroscopy laboratory (Institute of Chemistry, ASM). Melting points of synthesized compounds were determined on Boetius apparatus.

Thermogravimetric studies of synthesized combinations were performed on Paulik-Paulik-Erdei derivatograph, in the temperature range $20-500^{\circ} \mathrm{C}$ in air. Heating speed was $5^{\circ} \mathrm{C} / \mathrm{min}$ and $\mathrm{Al}_{2} \mathrm{O}_{3}$ was used as a standard. Samples weighing $50 \mathrm{mg}$ were placed in platinum crucible. DTA measurement sensitivity $-1 / 5$ and DTG - 1/5, TG - 100/100.

IR spectra were recorded on FT-IR Perkin Elmer "Spectrum 100" spectrometer $\left(4000 \div 650 \mathrm{~cm}^{-1}\right)$ and Specord M $80\left(4000 \div 250 \mathrm{~cm}^{-1}\right)$.

UV-Vis spectra were obtained using Perkin-Elmer "Lambda 25" spectrophotometer. The solutions of complexes I-III and the starting ligand 4,5-diphenylimidazole in two solvents with different polarity (isopropanol and ethanol). Electronic spectra were obtained at different concentrations of the solutions to calculate the extinction coefficient in each case.

NMR spectra were obtained on Bruker Avance spectrometer (400 MHz). Both ${ }^{1} \mathrm{H}$ NMR spectra and ${ }^{13} \mathrm{C}$ NMR were recorded in $\mathrm{CD}_{3} \mathrm{COCD}_{3}$ and reported to the reference signal of TMS taken as internal standard.

Magnetic measurements were done at room temperature ( $287 \mathrm{~K}-283 \mathrm{~K})$ by Gouy method on an installation from Institute of Chemistry. The experimental magnetic susceptibility data values were corrected by Pascal constants [9]. As a standard sample was used doubly distilled water. cobalt(II)

Synthesis of $\left[\mathrm{Co}\left(\mathrm{C}_{3} \mathrm{~N}_{2}\left(\mathrm{C}_{6} \mathrm{H}_{5}\right)_{2} \mathrm{NO}_{2}\right)_{2}\left(\mathrm{CH}_{3} \mathrm{OH}\right)_{2}\right](\mathrm{I}) \quad-\quad$ bis(4,5-diphenyl-2-nitroimidazolyl)bis(methanol)

A mixture of $0,093 \mathrm{~g}(0,32 \mathrm{mmol}) \mathrm{Co}\left(\mathrm{NO}_{3}\right)_{2} \cdot 6 \mathrm{H}_{2} \mathrm{O}$ and $0,141 \mathrm{~g}(0,64 \mathrm{mmol})$ of 4,5-diphenylimidazole in 10 $\mathrm{ml} \mathrm{CH} 3 \mathrm{OH}$ was heated at $170^{\circ} \mathrm{C}$ for 3 hours in a Teflon-lined autoclave, which were cooled to $30^{\circ} \mathrm{C}$ at a rate of $0,06^{\circ} \mathrm{C}$ per minute. Red-brown needle-shaped crystals were washed three times with methanol and air dried. Yield $-0,07 \mathrm{~g}$ $(33,6 \%)$.

The results of elemental analysis, \%: Found: C 58,67; H 4,47; N 12,40; Co 9,03. Calculated for $\mathrm{C}_{32} \mathrm{H}_{28} \mathrm{~N}_{6} \mathrm{O}_{6} \mathrm{Co}$ : C 58,99; H 4,33; N 12,90; Co 9,05. Melting point: $\mathrm{mp}>355^{\circ} \mathrm{C}$.

IR spectrum $\left(\mathrm{cm}^{-1}\right): 3657(\mathrm{w}), 2989(\mathrm{~m}), 2902(\mathrm{~m}), 2772(\mathrm{~m}), 2542(\mathrm{~m}), 1605(\mathrm{w}), 1577(\mathrm{w}), 1523(\mathrm{w}), 1499(\mathrm{~s})$, 1468(m), 1437(vs), 1388(vs), 1314(m), 1286(m), 1269(s), 1241(m), 1150(vs), 1099(s), 1073(m), 1032(m), 1018(vs), 1009(vs), 976(s), 919(m), 833(m), 784(m), 772(m), 740(w), 734(m), 696(s), 680(m), 661(m), 535(w), 512(w), 487(w). nickel(II)

Synthesis of $\left[\mathrm{Ni}\left(\mathrm{C}_{3} \mathrm{~N}_{2}\left(\mathrm{C}_{6} \mathrm{H}_{5}\right)_{2} \mathrm{NO}_{2}\right)_{2}\left(\mathrm{CH}_{3} \mathrm{OH}\right)_{2}\right](\mathrm{II}) \quad-\quad$ bis(4,5-diphenyl-2-nitroimidazolyl)bis(methanol)

Compound II was obtained by the same procedure as I, using $0,093 \mathrm{~g}(0,32 \mathrm{mmol})$ of $\mathrm{Ni}\left(\mathrm{NO}_{3}\right)_{2} \cdot 6 \mathrm{H}_{2} \mathrm{O}$ and 0,141 $\mathrm{g}(0,64 \mathrm{mmol})$ of 4,5-diphenylimidazole. Yellow-brown needle-shaped crystals were washed three times with methanol and air dried. Yield - 0,11 g (52,8\%).

The results of elemental analysis, \%: Found: $\mathrm{C} 58,78 ; \mathrm{H} 4,50 ; \mathrm{N} \mathrm{12,65;} \mathrm{Ni} \mathrm{9,00.} \mathrm{Calculated} \mathrm{for} \mathrm{C}_{32} \mathrm{H}_{28} \mathrm{~N}_{6} \mathrm{O}_{6} \mathrm{Ni}_{\text {: }}$ C 59,01; H 4,33; N 12,90; Ni 9,01. Melting point: $\mathrm{mp}>355^{\circ} \mathrm{C}$.

IR spectrum $\left(\mathrm{cm}^{-1}\right):$ 3676(w), 2988(m), 2901(m), 2796(m), 1604(w), 1576(w), 1500(m), 1467(m), 1438(s), 1387(vs), 1314(m), 1285(m), 1265(s), 1241(m), 1150(vs), 1099(s), 1073(s), 1015(vs), 976(s), 918(m), 835(m), 783(m), 772(m), 740(m), 733(m), 696(s), 679(m), 662(m), 537(w), 511(w), 488(w). 

zinc(II)

Synthesis of $\left[\mathrm{Zn}\left(\mathrm{C}_{3} \mathrm{~N}_{2}\left(\mathrm{C}_{6} \mathrm{H}_{5}\right)_{2} \mathrm{NO}_{2}\right)_{2}\left(\mathrm{CH}_{3} \mathrm{OH}\right)_{2}\right](\mathrm{III}) \quad-\quad$ bis(4,5-diphenyl-2-nitroimidazolyl)bis(methanol)

Compound III was obtained by the same procedure as I, using 0,095 $\mathrm{g}(0,32 \mathrm{mmol})$ of $\mathrm{Zn}\left(\mathrm{NO}_{3}\right)_{2} \cdot 6 \mathrm{H}_{2} \mathrm{O}$ and $0,141 \mathrm{~g}(0,64 \mathrm{mmol})$ of 4,5-diphenylimidazole. Orange needle crystals were washed three times with methanol and air dried. Yield - 0,14 g $(67,0 \%)$.

The results of elemental analysis, \%: Found: C 58,13; $\mathrm{H} \mathrm{4,42;} \mathrm{N} \mathrm{12,95;} \mathrm{Zn} \mathrm{9,54.} \mathrm{Calculated} \mathrm{for} \mathrm{C}_{32} \mathrm{H}_{28} \mathrm{~N}_{6} \mathrm{O}_{6} \mathrm{Zn}_{\text {: }}$ C 58,41; H 4,27; N 12,77; Zn 9,94. Melting point: $\mathrm{mp}=291-293^{\circ} \mathrm{C}$.

IR spectrum $\left(\mathrm{cm}^{-1}\right): 3649(\mathrm{~m}), 2988(\mathrm{~m}), 2901(\mathrm{~m}), 2796(\mathrm{w}), 1603(\mathrm{~m}), 1577(\mathrm{w}), 1502(\mathrm{~m}), 1471(\mathrm{~m}), 1457(\mathrm{~m})$, 1438(s), 1401(vs), 1293(s), 1265(s), 1233(m), 1157(vs), 1099(s), 1076(m), 1045(s), 1025(s), 975(s), 920(s), 833(m), 782(m), 770(s), 733(m), 695(s), 680(m), 657(w), 534(w), 510(w), 486(w).

${ }^{1} \mathrm{H}$ RMN spectrum (in $\left.\mathrm{CD}_{3} \mathrm{COCD}_{3}\right): \delta=3,00 \mathrm{ppm}(\mathrm{s}, 1 \mathrm{H}, \mathrm{OH}) ; 3,31$ şi $3,33 \mathrm{ppm}\left(\mathrm{d}, 3 \mathrm{H}, \mathrm{CH}_{3}\right) ; 3,85 \mathrm{ppm}(\mathrm{s}, 3 \mathrm{H}$, $\left.\mathrm{CH}_{3}\right) ; 7,22-7,56 \mathrm{ppm}\left(\mathrm{m}, \mathrm{CH}_{\mathrm{Ph}}\right)$.

Complexes I-III are soluble in ethanol, DMF, acetone, acetonitrile, slightly soluble in water, methanol, chloroform and toluene, insoluble in hexane and THF. The same compounds were obtained when the reactions were carried out in a mixture of methanol and water $(4: 1)$.

\section{Synthesis of $\mathrm{C}_{3} \mathrm{~N}_{2} \mathrm{H}\left(\mathrm{C}_{6} \mathrm{H}_{5}\right)_{2} \mathrm{NO}_{2}$ (IV) - 4,5-diphenyl-2-nitroimidazole}

$200 \mathrm{mg}(0,30 \mathrm{mmol})$ of complex III was boiled $30 \mathrm{~min}$ in reflux with an excess of $\mathrm{H}_{2} \mathrm{SO}_{4}(2 \mathrm{ml})$ and water (10 $\mathrm{ml})$. After the demetallation of complex, the $\mathrm{pH}$ of solution was adjusted to 3-4 using a saturated $\mathrm{Na}_{2} \mathrm{CO}_{3}$ aqueous solution, then organic components of aqueous phase were extracted in chloroform $(3 \times 10 \mathrm{ml})$. The extract was dried over anhydrous $\mathrm{Na}_{2} \mathrm{SO}_{4}$, concentrated to $15 \mathrm{ml}$ and allowed to evaporate. After two days were obtained yellow aciforme crystals, which were filtered and dried in air. Yield - $142 \mathrm{mg}$ (88\%). The compound is soluble in toluene, chloroform, acetone, and methanol and insoluble in water.

The results of elemental analysis, \%: Found: $\mathrm{C} 81,76 ; \mathrm{H} 4,28 ; \mathrm{N} \mathrm{15,36}$; Calculated for $\mathrm{C}_{15} \mathrm{H}_{11} \mathrm{~N}_{3} \mathrm{O}_{2}: \mathrm{C} 82,19 ; \mathrm{H}$ 4,15; N 15,85. Melting point: $\mathrm{mp}=216-218^{\circ} \mathrm{C}$.

IR spectrum $\left(\mathrm{cm}^{-1}\right): 3055(\mathrm{~m}), 2923(\mathrm{~m}), 2693(\mathrm{~m}), 1605(\mathrm{w}), 1577(\mathrm{w}), 1539(\mathrm{~m}), 1483(\mathrm{~m}), 1436(\mathrm{~s}), 1408(\mathrm{vs})$, 1349(vs), 1319(m), 1287(m), 1262(m), 1193(m), 1159(s), 1092(m), 1075(m), 1021(s), 969(m), 924(m), 842(m), 826(s), 783(m), 765(s), 734(m), 727(m), 694(vs), 675(m).

${ }^{1} \mathrm{H}$ RMN spectrum $\left(\mathrm{CD}_{3} \mathrm{COCD}_{3}\right): \delta=7,14-7,58 \mathrm{ppm}$ (multiplet, $\left.10 \mathrm{H}, \mathrm{CH}_{\mathrm{Ph}}\right) \cdot{ }^{13} \mathrm{C} \mathrm{RMN} \mathrm{spectrum}\left(\mathrm{CD}_{3} \mathrm{COCD}_{3}\right)$ : $\delta=125,23 \mathrm{ppm}$ (singlet, C2 Im); 128,15 - 128,87 ppm (multiplet, $\mathrm{C}_{\mathrm{Ph}}$ ).

\section{Acknowledgments}

We are thankful to our collegues from the Laboratories of Analitical Chemistry and Atomic Absorption Spectroscopy for elemental analysis and IR spectra of our compounds.

This work was supported by the Research Project (11.832.08.12A) of State Program and Institutional Project (11.817.08.24A).

\section{References}

[1]. Bioinorganic Medicinal Chemistry, WILEY-VCH Verlag GmbH \& Co. KGaA Edition, 2011, p. 17.

[2]. Charlson, R. H., Brown T. L., Inorg. Chem., 5, 1966, p. 268.

[3]. G. Eihgorn, „Neorganičeskaya biohimiya”, Izd. Mir, Moskva, 1978, T. 1-2.

[4]. Palamaru M. N., Iordan A. R., Cecal A. „Chimie bioanorganică şi metalele vieții”, Ed. BIT, Iaşi, 1997, p. 395.

[5]. Wang Bo, Côte A. P., Furukawa H., O’Keeffe, M., Yaghi, O. M., Nature, 453, 2008, p. 207.

[6]. Banerjee R., Phan A., Wang B., Knobler C., Furukawa H., O’Keeffe M., Yaghi O.M., Science, 319, 2008, p. 939.

[7]. Nakamoto, K. „IK spektry i spektry KR neorganičeskih i koordinacionnyh soedinenii”, Izd. Mir, Moskva, 1991, $536 \mathrm{~s}$.

[8]. Avram, M., Mateescu, Gh. D. „Spectroscopia în infraroşu. Aplicaţii în chimia organică”, Ed. Tehnică, Bucureşti, 1966, p. 591.

[9]. Dpago, R., „Fizičeskie metody v himii”, Izd. Mir, Moskva, 1981, 422 s.

[10]. M. Străjescu, F. Teodor, „Elemente de chimie bioanorganică”, Ed. Dacia, Bucureşti, 1979, p. 438.

[11]. Ciumacov, Iu., Jeanneau, E., Voda, I., Druta, V., Indricean, C., Turta, C. Russ. J. Struct. Chem, 2012, (in press).

[12]. Klimova V. A. „Osnovnye mikrometody analiza organičeskih soedinenii”, 2 izd., Moskva, 1975, s. 19-70. 